\title{
Wintering in Antarctica: Impact on Immune Response of Indian Expeditioners
}

\author{
Anand Prakash Yadav Kamla Prasad Mishra Lilly Ganju Shashi Bala Singh \\ Immunomodulation Laboratory, Defence Institute of Physiology and Allied Sciences, Delhi, India
}

\section{Key Words}

Antarctica $\cdot$ Stress $\cdot$ Isolation $\cdot$ Cytokines $\cdot \lg A$

\begin{abstract}
The immune system is one of the major thrust areas in understanding the effects of adverse climatic conditions on human health. Exposure to the Antarctic environment, such as isolation, cold, UV radiations, magnetic field, blizzards, circadian biorhythms, and fear of the unknown, modify various components of the immune system. Members of Antarctic expeditions suffer significant emotional strain as a result of physical isolation and social deprivation. The present study was performed on winter team members of the 28th Indian Scientific Expedition. In this study, different immunological parameters, which mainly include cytokines (TNF- $\alpha$, IFN- $\gamma$, TGF- $\beta$, and IL-4), chemokine MIP-1 $\alpha$, immunoglobulins (IgA, $\lg M$ and $\lg G$ ), cortisol and netrin-1, were assayed in sera by ELISA. Results showed that TNF- $\alpha$ and MIP-1 $\alpha$ levels were significantly increased in March, May and August while IFN- $\gamma$ levels were increased in March and May while TGF- $\beta$ levels showed a significant decrease in March and May. Serum IgA levels were significantly increased during the entire period of the stressful expedition. Therefore, the present study suggests that serum IgA could be a potential biomarker for extreme environmental conditions.
\end{abstract}

Copyright $\odot 2012$ S. Karger AG, Basel
(C) 2012 S. Karger AG, Basel

$1021-7401 / 12 / 0196-0327 \$ 38.00 / 0$

Fax +4161306 1234

E-Mail karger@karger.ch

www.karger.com
Accessible online at: www.karger.com/nim

\section{Introduction}

Exposure to different stresses, like extreme cold, heat, strong magnetic field, UV radiations, high wind velocity, altered circadian biorhythms along with psychological stress, has been known to modulate the functionality of different components of the immune system [1-3]. The healthy, transient population who 'winter' at Indian research base Maitri, Antarctica, generally come from densely populated tropical regions and get suddenly confined to this extreme environment. Most of the expeditioners are totally isolated physically for periods of 8-13 months that are excellent analogues for long-term spaceflights [2]. Thus individuals participating in Antarctic expeditions, along with the physiological stress mentioned above, suffer significant emotional strain as a result of physical isolation and social deprivation [4]. Medical research performed for the past 50 years on the different Antarctic Research Expeditions reported certain changes in immune functions [5]. Severe environmental stress may have immunosuppressive effects, resulting in increased risk for immune-related disorders, such as infectious diseases, allergy, cancer and autoimmune disorders. Muller et al. [6] have reported diminished delayedtype hypersensitivity to recall antigens in more than 250 study subjects in Antarctica compared with control sub- 
jects stationed on Macquarie Island, which is known for its harsh winter climate, but where access to the mainland is possible. A typical monocytosis was detected and a striking reduction in the proinflammatory cytokine was noted [7]. Decreased serum levels of IL-10, IL-6, IL-1 receptor antagonist [8] and IL-1 $\beta$ were detected [9]. It has been recognized that cold stress affects various aspects of both cellular and humoral immunity in experimental animals: it decreases lymphocyte proliferation, natural killer cell count and cytolytic activity; it activates complement and induces heatshock proteins [10-12]. Elevation of IFN- $\gamma$ was reported during exposure to an Antarctic winter [2]. There is also some evidence that psychological stress may affect many aspects of the integrative network between the immune, central nervous and endocrine systems in both animals and humans $[13,14]$. The complex effects of psychological stress on the interactions among these three systems need to be investigated in detail.

The present study was performed on the winter team of the 28th Indian Scientific Expedition to Antarctica. In this study, different immunological parameters, which mainly include cytokines, chemokine and immunoglobulins, were assayed in serum. Other immunomodulatory signature molecules, like cortisol and the neuronal guide molecule netrin-1, known to have anti-inflammatory activity, were also analyzed. Our results show significant alterations in cytokines, immunoglobulins and cortisol levels in the wintering expeditioners as compared with their baseline levels.

\section{Methods}

\section{Subjects}

Twenty-two members (all males) of the wintering team of the 28th Indian Scientific Expedition to Antarctica volunteered to participate in this study. Ages ranged from 25 to 60 years, with a mean age of 36 years. All had undergone predeparture clinical, psychological and laboratory examinations to ensure a healthy population for the isolation during the Antarctic stay. The study was conducted at the Indian Maitri research base, Antarctica. Blood was drawn from the expeditioners in October 2008 before leaving India to Antarctica, and in March, May, August and November 2009. None of the subjects had any signs or symptoms indicative of infection at the time of the study, nor had they used drugs that could significantly affect the immunological parameters. Informed consent was obtained from each of the subjects involved in the study.

\section{Serum Separation}

The blood drawn $(10 \mathrm{ml})$ from the expeditioners was collected in the morning in unheparinized vials and was incubated for $1 \mathrm{~h}$ at $37^{\circ} \mathrm{C}$. Blood clot formation left a clear serum above, which was slowly removed and collected in fresh Eppendorf tubes and cen- trifuged at 1,200 rpm for $10 \mathrm{~min}$ to remove RBCs if any left. The clear serum was collected in small aliquots and stored at $-70^{\circ} \mathrm{C}$ for further analysis.

Cytokine and Chemokine Assays

Cytokines IFN- $\gamma$, TNF- $\alpha$, TGF- $\beta$, IL- 4 and chemokine MIP$1 \alpha$ assays were carried out using a solid-phase enzyme immunoassay with ELISA kits (Pierce, USA) based on the multiple-antibody sandwich principle. The ELISA plates were coated with mouse monoclonal antibody specific for human IL-4, IFN- $\gamma$, TNF- $\alpha$, TGF- $\beta$ and MIP- $1 \alpha$ to capture the specific cytokines present in the standard and serum. Anti-IL-4, anti-IFN- $\gamma$, antiTNF- $\alpha$, anti-TGF- $\beta$ and anti-MIP- $1 \alpha$ rabbit polyclonal antibody conjugated to biotin was added to each well, followed by streptavidine/HRP incubation for $20 \mathrm{~min}$. At the end, color was developed using peroxide $/ 3^{\prime}, 3^{\prime}, 5,5^{\prime}$-tetramethylbenzidine (TMB) substrate solution. The substrate initiated a peroxidase-catalyzed color change, which was stopped within 15 min by acidification with stop solution. Absorbance was measured at $450 \mathrm{~nm}$ in an ELISA reader (Biotek, USA).

\section{Immunoglobulin Assay}

Three types of immunoglobulins, i.e. IgA, IgG and IgM, were measured by the double-antibody sandwich ELISA method as per the manufacturer's instructions (ICL, USA). Briefly, IgA, IgG and IgM were measured in serum by capture ELISA using human immunoglobulin reference serum (ICL), goat anti-human IgA, G and $\mathrm{M}$ conjugated to HRP were added. Following washing steps, the enzyme bound to the immunosorbent was assayed by addition of a chromogenic substrate, TMB. After 20 min of incubation at room temperature, stop solution $\left(2 \mathrm{~N} \mathrm{H}_{2} \mathrm{SO}_{4}\right)$ was added. The absorbance was measured at $450 \mathrm{~nm}$ in an ELISA reader (Biotek). The quantities of immunoglobulins in the test samples were interpolated from the standard curve constructed from the standards and correlated for sample dilution.

\section{Cortisol Assay}

Cortisol was assayed in serum using ELISA as per the manufacturer's instructions (Diagnostic Biochem, Canada). Briefly, anti-cortisol antibody-coated micro-well plates incubated with 20 $\mu l$ of either standard or serum samples followed by $100 \mu \mathrm{l}$ of the cortisol-HRP were incubated on a plate shaker at $200 \mathrm{rpm}$ for 45 min at room temperature. Plates were washed three times with wash buffer. At the end, color was developed using peroxide/TMB substrate solution which was stopped within $15 \mathrm{~min}$ by acidification with $1 \mathrm{~N} \mathrm{HCl}$. Absorbance was measured at $450 \mathrm{~nm}$ in an ELISA reader (Biotek).

\section{Netrin-1 Assay}

Netrin-1 was assayed with a kit following the manufacturer's instructions (Cusabio Biotech, China). The microtiter plate provided in the kit was precoated with an antibody specific to netrin-1. Standards and samples were added to the plate, followed by a biotin-conjugated antibody preparation specific for netrin-1. Then a solution of HRP-conjugated avidin was added. The penultimate step included addition of TMB substrate. The final step included termination of the reaction by addition of $1 \mathrm{~N}$ sulfuric acid solution. Absorbance was measured at $450 \mathrm{~nm}$ in an ELISA reader (Biotek). 


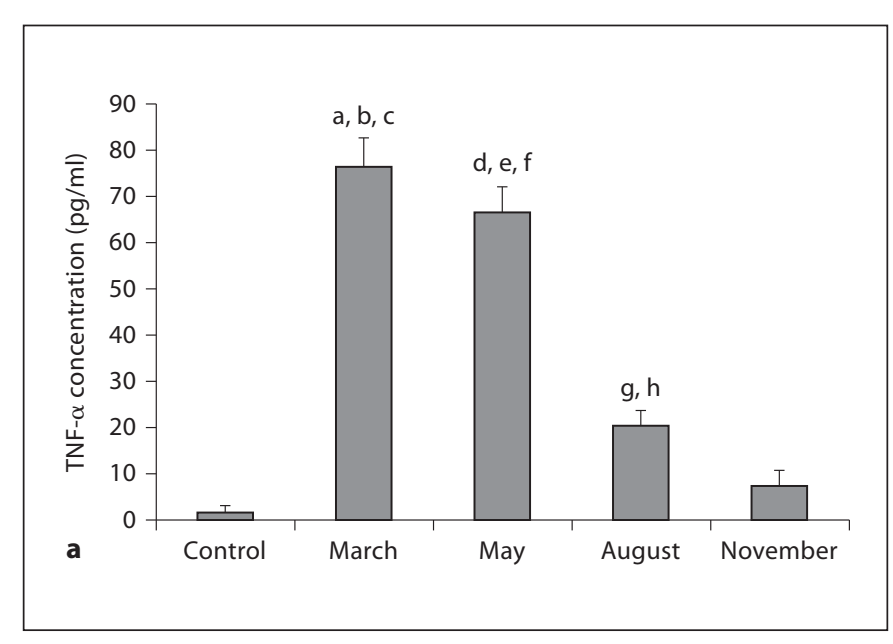

Fig. 1. Sequential variation in serum TNF- $\alpha$ (a), IFN- $\gamma(\mathbf{b})$ and TGF- $\beta$ (c) levels in Indian Antarctic expeditioners before leaving India (control) and during their stay at Maitri, Antarctica, in March, May, August and November. Data are presented as means \pm SEs. $\mathrm{a}^{\mathrm{a}} \mathrm{p}<0.005$ March vs. August, ${ }^{\mathrm{b}} \mathrm{p}<0.001$ March vs. November, ${ }^{c} \mathrm{p}<0.001$ control vs. March, ${ }^{\mathrm{d}} \mathrm{p}<0.001$ control vs. May, ${ }^{\mathrm{e}} \mathrm{p}<0.005$ May vs. August, ${ }^{\mathrm{f}} \mathrm{p}<0.005$ May vs. November, ${ }^{\mathrm{g}} \mathrm{p}<$ 0.001 control vs. August, and ${ }^{\mathrm{h}} \mathrm{p}<0.05$ August vs. November. b a $\mathrm{p}<0.005$ control vs. March, ${ }^{\mathrm{b}} \mathrm{p}<0.001$ March vs. August, ${ }^{\mathrm{c}} \mathrm{p}<0.001$ March vs. November, ${ }^{\mathrm{d}} \mathrm{p}<0.005$ control vs. May, ${ }^{\mathrm{e}} \mathrm{p}<0.001$ May vs. August, ${ }^{\mathrm{f}} \mathrm{p}<0.001$ May vs. November, ${ }^{\mathrm{g}} \mathrm{p}<$ 0.05 control vs. August, and ${ }^{\mathrm{h}} \mathrm{p}<0.001$ control vs. November. c $^{\text {a }} \mathrm{p}<0.005$ March vs. May, ${ }^{b} \mathrm{p}<0.05$ March vs. August, ${ }^{\mathrm{c}} \mathrm{p}<$ 0.01 control vs. May, ${ }^{\mathrm{d}} \mathrm{p}<0.01$ control vs. August, ${ }^{\mathrm{e}} \mathrm{p}<0.05$ May vs. August, ${ }^{\mathrm{f}} \mathrm{p}<0.05$ control vs. November, ${ }^{\mathrm{g}} \mathrm{p}<0.005$ May vs. November, and ${ }^{\mathrm{h}} \mathrm{p}<0.05$ August vs. November.

\section{Statistical Analysis}

Values are represented as means \pm SEs. Comparison between results of March, May, August, November and controls were performed using an ANOVA followed by post hoc analysis with Dunnett's test. The entire analysis was conducted using SPSS 15 software. $p \leq 0.05$ was considered significant.

\section{Results}

\section{Serum Cytokines}

TNF- $\alpha$ Levels

Analysis of serum TNF- $\alpha$ in wintering expeditioners revealed that the mean baseline control level was $1.51 \pm$ $1.5 \mathrm{pg} / \mathrm{ml}$ (fig. 1a). After reaching Antarctica, the level significantly increased to $76 \pm 6.4 \mathrm{pg} / \mathrm{ml}$ in March compared with the baseline level $(\mathrm{p}<0.001)$. In May, it decreased to $66 \pm 5.5 \mathrm{pg} / \mathrm{ml}$ but was significantly increased compared with the control level $(\mathrm{p}<0.001)$. In August,
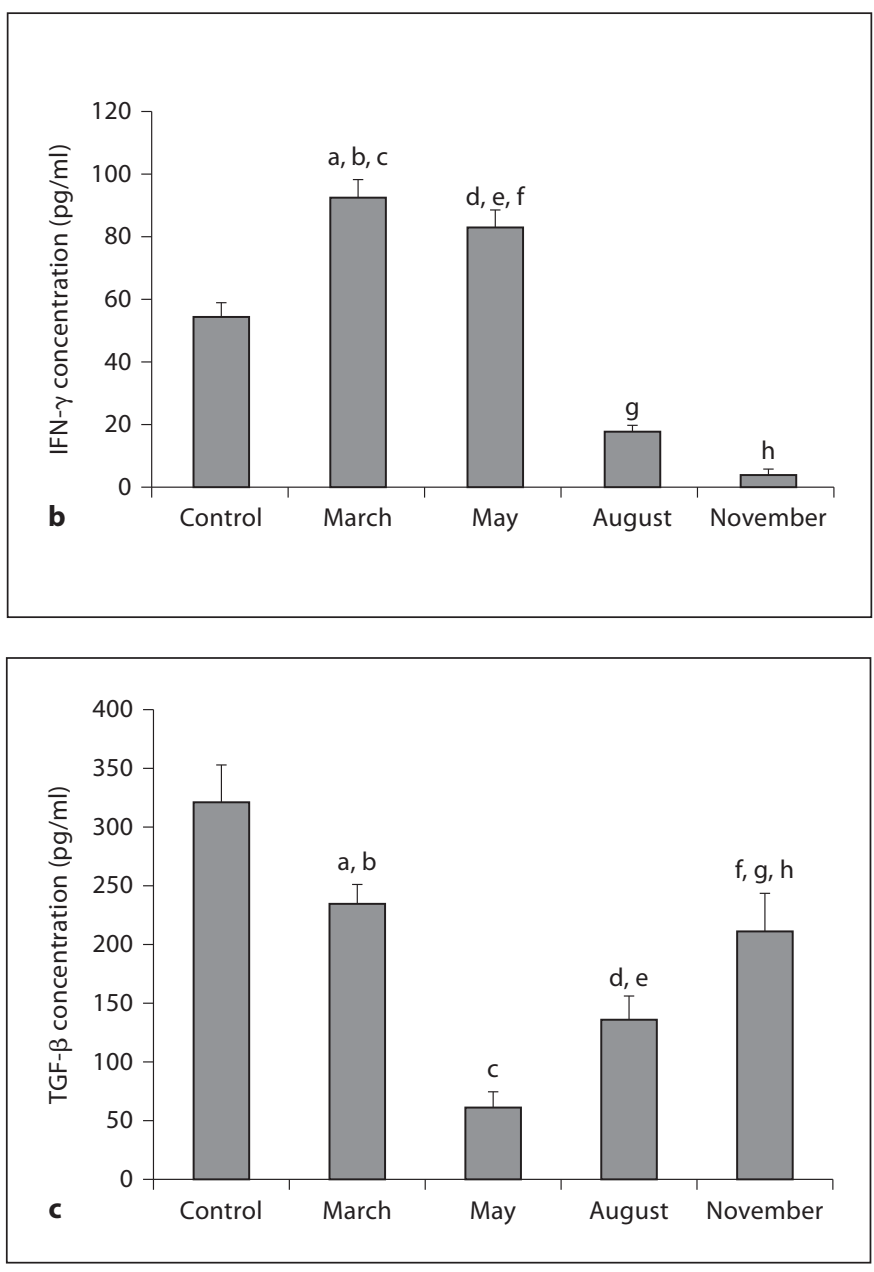

the TNF- $\alpha$ level significantly decreased to $20 \pm 3.4 \mathrm{pg} /$ $\mathrm{ml}$ compared with March $(\mathrm{p}<0.005)$ and May $(\mathrm{p}<0.005)$ but remained significantly increased compared with the control level $(\mathrm{p}<0.001)$. The level further significantly decreased to $7.32 \pm 3.20 \mathrm{pg} / \mathrm{ml}$ in November compared with March $(\mathrm{p}<0.001)$, May $(\mathrm{p}<0.005)$ and August $(\mathrm{p}<$ 0.05).

\section{IFN- $\gamma$ Levels}

IFN- $\gamma$, a cytokine critical for innate and adaptive immunity against viral and intracellular bacterial infections and for tumor control, was measured in the serum of expeditioners. The baseline control level of serum IFN- $\gamma$ was $54 \pm 5.2 \mathrm{pg} / \mathrm{ml}$ (fig. 1b). The IFN- $\gamma$ level was significantly increased to $92 \pm 6.5 \mathrm{pg} / \mathrm{ml}$ in March (p< 0.005 ) compared with the control level. Further, in May, the level decreased to $83 \pm 6 \mathrm{pg} / \mathrm{ml}$ compared with March but remained significantly higher than the con- 
trol level $(\mathrm{p}<0.005)$. However, in August, the IFN- $\gamma$ level dramatically decreased to $18 \pm 2.3 \mathrm{pg} / \mathrm{ml}$, a significant decrease compared with the control level $(\mathrm{p}<0.05)$, and the levels in March $(\mathrm{p}<0.001)$ and May $(\mathrm{p}<0.001)$. The level further decreased to $3.69 \pm 2.12 \mathrm{pg} / \mathrm{ml}$ in November, a significant decrease compared with the control lev$\mathrm{el}(\mathrm{p}<0.001)$, and the levels in March $(\mathrm{p}<0.001)$ and May $(\mathrm{p}<0.001)$.

\section{IL-4 Levels}

The signature cytokine for Th2 immunity is IL-4; it was not detected at any time point of sampling in Indian Antarctic expeditioners (data not shown).

\section{TGF- $\beta$ Levels}

The TGF- $\beta$ level was $322 \pm 32 \mathrm{pg} / \mathrm{ml}$ in the baseline control samples and was significantly decreased at each time point of sampling during the entire period of isolation (fig. 1c). In March, the level was $236 \pm 16 \mathrm{pg} / \mathrm{ml}$ $(\mathrm{p}<0.05$ vs. control) and was further decreased to $63 \pm$ $13 \mathrm{pg} / \mathrm{ml}$ in May $(\mathrm{p}<0.001$ vs. control, $\mathrm{p}<0.005$ vs. March). However, the level was significantly increased to $137 \pm 21 \mathrm{pg} / \mathrm{ml}$ in August compared with May $(\mathrm{p}<0.05)$ but it was significantly lower compared with March ( $<<$ $0.05)$. Furthermore, the level increased to $212 \pm 33 \mathrm{pg} / \mathrm{ml}$ in November compared with August $(\mathrm{p}<0.05)$ and May $(\mathrm{p}<0.05)$.

\section{MIP-1 $\alpha$ Levels}

MIP-1 $\alpha$, a chemokine generally involved in acute inflammatory states, was measured in the serum samples of Antarctic wintering personnel (fig. 2). The baseline control level was $2.5 \pm 1 \mathrm{pg} / \mathrm{ml}$. It was observed that after reaching Antarctica, the levels initially increased significantly to $189 \pm 16 \mathrm{pg} / \mathrm{ml}$ in March $(\mathrm{p}<0.001)$ compared with the control level and then gradually decreased to 162 $\pm 16 \mathrm{pg} / \mathrm{ml}$ in May, but the level remained significantly higher compared with the control level $(p<0.001)$; the level further significantly decreased to $82 \pm 10 \mathrm{pg} / \mathrm{ml}$ in August compared with March $(\mathrm{p}<0.01)$ and May $(\mathrm{p}<$ 0.01 ) but remained significantly high compared with the control level $(\mathrm{p}<0.01)$. Further, the levels were drastically reduced to $18 \pm 7 \mathrm{pg} / \mathrm{ml}$ in November compared with March ( $\mathrm{p}<0.005)$, May $(\mathrm{p}<0.005)$ and August $(\mathrm{p}<$ 0.005).

\section{Serum Immunoglobulins}

IgA Levels

The concentrations of serum $\operatorname{IgA}$ at various time points are shown in figure $3 \mathrm{a}$. It was observed that after

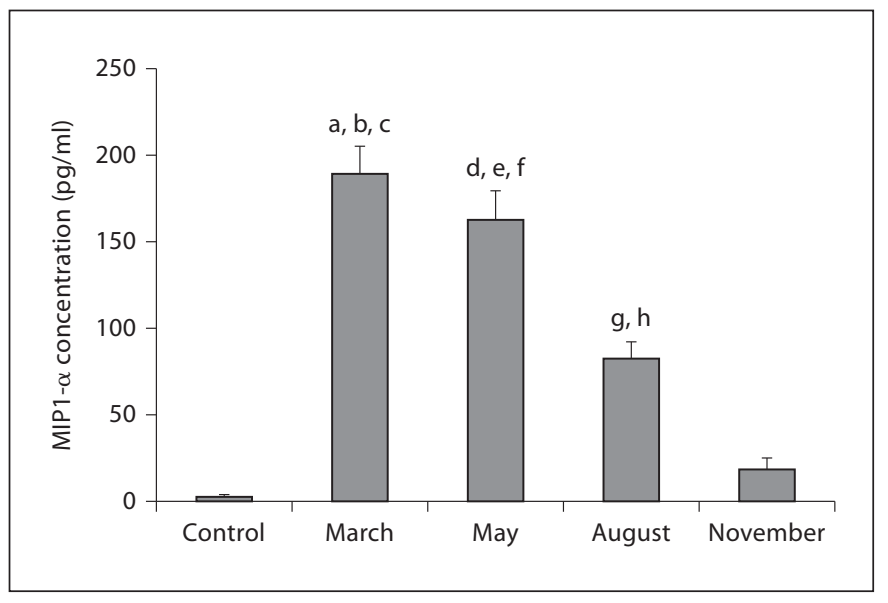

Fig. 2. MIP-1 $\alpha$ level in Indian Antarctic expeditioners before leaving India (control) and during their stay at Maitri, Antarctica, in March, May, August and November. Data are presented as means \pm SEs. ${ }^{\mathrm{a}} \mathrm{p}<0.001$ control vs. March, ${ }^{\mathrm{b}} \mathrm{p}<0.01$ March vs. August, ${ }^{\mathrm{c}} \mathrm{p}<0.005$ March vs. November, ${ }^{\mathrm{d}} \mathrm{p}<0.001$ control vs. May, ${ }^{\mathrm{e}} \mathrm{p}<$ 0.01 May vs. August, ${ }^{\mathrm{f}} \mathrm{p}<0.005$ May vs. November, ${ }^{\mathrm{g}} \mathrm{p}<0.01$ control vs. August, ${ }^{\mathrm{h}} \mathrm{p}<0.05$ August vs. November.

reaching Antarctica, the IgA levels were significantly increased at all time points compared with baseline. The baseline control level of IgA, which was $607 \pm 26 \mathrm{mg} / \mathrm{dl}$, was significantly increased to $999 \pm 29 \mathrm{mg} / \mathrm{dl}(\mathrm{p}<0.001)$ in March. It was further significantly increased to 1,188 $\pm 65 \mathrm{mg} / \mathrm{dl}$ ( $\mathrm{p}<0.001 \mathrm{vs}$. control) in May. However, the IgA level was decreased to $1,005 \pm 41 \mathrm{mg} / \mathrm{dl}$ in August but remained significantly high compared with the control level $(\mathrm{p}<0.001)$. It was further significantly decreased to $859 \pm 25 \mathrm{mg} / \mathrm{dl}$ in November compared with March $(\mathrm{p}<0.05)$, May $(\mathrm{p}<0.05)$ and August $(\mathrm{p}<0.05)$ but was significantly increased compared with the control level $(\mathrm{p}<0.001)$.

\section{IgM Levels}

The concentrations of serum IgM were measured at different time points in Antarctic wintering personnel as shown in figure $3 \mathrm{~b}$. No significant alteration was observed at any time point before leaving or during the Antarctic isolation.

\section{IgG Levels}

The concentrations of serum $\operatorname{IgG}$ at various time points are shown in figure $3 \mathrm{c}$. The baseline value of $\operatorname{IgG}$ was $1,953 \pm 54 \mathrm{mg} / \mathrm{dl}$. It increased to $1,995 \pm 46$ and 2,046 $\pm 53 \mathrm{mg} / \mathrm{dl}$ in March and May, respectively. The IgG level significantly decreased to $1,830 \pm 282 \mathrm{mg} / \mathrm{dl}$ in 


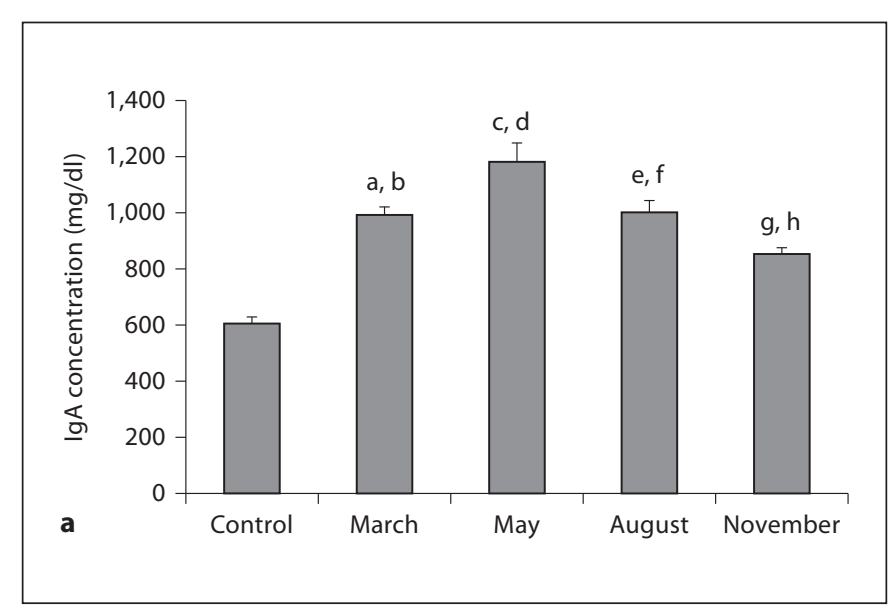

Fig. 3. Serum IgA (a), IgM (b) and IgG (c) levels in Indian Antarctic expeditioners before leaving India (control) and during their stay at Maitri, Antarctica, in March, May, August and November. Data are presented as means \pm SEs. $\mathbf{a}^{\mathrm{a}} \mathrm{p}<0.001$ control vs. March, ${ }^{\mathrm{b}} \mathrm{p}<0.05$ March vs. November, ${ }^{\mathrm{c}} \mathrm{p}<0.001$ control vs. May, ${ }^{\mathrm{d}} \mathrm{p}<0.05$ May vs. November, ${ }^{\mathrm{e}} \mathrm{p}<0.001$ control vs. August, ${ }^{\mathrm{f}} \mathrm{p}<0.05$ August vs. November, ${ }^{\mathrm{g}} \mathrm{p}<0.001$ control vs. November, and ${ }^{\mathrm{h}} \mathrm{p}<0.05$ May vs. November. $\mathrm{c}^{\mathrm{a}} \mathrm{p}<0.05$ May vs. August.

August compared with May $(\mathrm{p}<0.05)$ and March. The level was further increased to $1,954 \pm 28 \mathrm{mg} / \mathrm{dl}$ in November.

\section{Cortisol Level}

Cortisol, usually referred as 'stress hormone', was measured in the serum samples of Antarctic wintering personnel at different time points (fig. 4a). The baseline level of cortisol was $14.3 \pm 1.24 \mu \mathrm{g} / \mathrm{dl}$ and increased to $18.6 \pm 2.4$ and $19.6 \pm 2.4 \mu \mathrm{g} / \mathrm{dl}$ in March and May, respectively. The level further increased to $24 \pm 2 \mu \mathrm{g} / \mathrm{dl}$ in August; this increase was significant compared with the control level $(\mathrm{p}<0.05)$. However, in November, the level significantly decreased to $16.5 \pm 2.2 \mu \mathrm{g} / \mathrm{dl}$ compared with August $(\mathrm{p}<0.05)$.

\section{Netrin-1 Level}

Netrin-1, an anti-inflammatory neuronal guide molecule, was measured in the serum samples of Antarctic
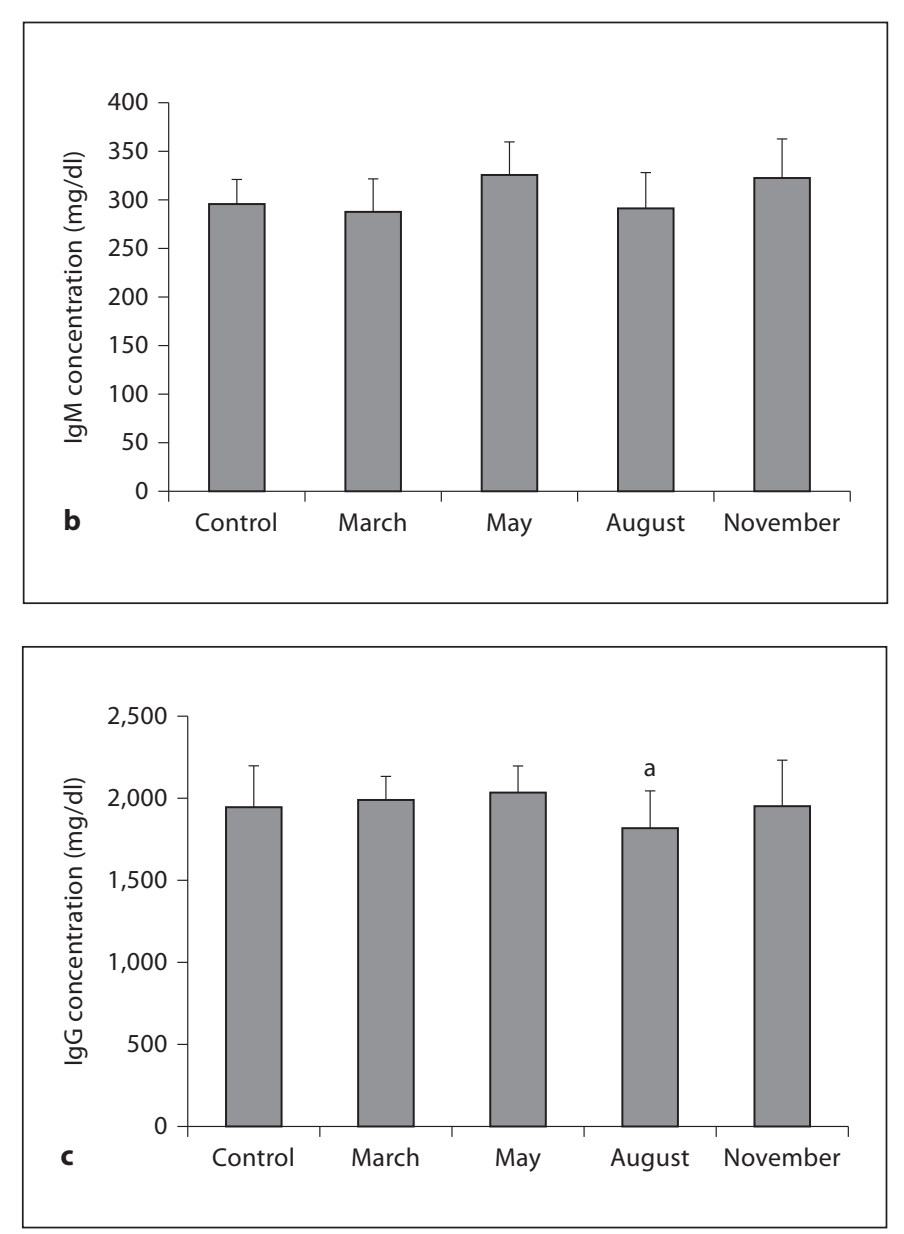

wintering personnel at different time points as shown in figure $4 \mathrm{~b}$. No significant alteration was observed at any time point. The netrin-1 level in the baseline control sample was $779 \pm 101 \mathrm{pg} / \mathrm{ml}$ and decreased to $614 \pm 100 \mathrm{pg} /$ $\mathrm{ml}$ in March. This level increased to $742 \pm 102 \mathrm{pg} / \mathrm{ml}$ in May and then decreased to $566 \pm 80 \mathrm{pg} / \mathrm{ml}$ in August and increased to $821 \pm 134 \mathrm{pg} / \mathrm{ml}$ in November. The level of the anti-inflammatory molecule netrin-1 was not significantly altered during the entire isolation period in Antarctica.

\section{Discussion}

In this report, we studied the serum levels of TNF- $\alpha$, IFN- $\gamma$, TGF- $\beta$, IL- 4 , chemokine MIP- $1 \alpha$, IgA, IgM, IgG, stress hormone cortisol, netrin-1 of 22 Indian personnel exposed to Antarctic winter. TNF- $\alpha$ and MIP-1 $\alpha$ levels were significantly increased in March, May and August. 

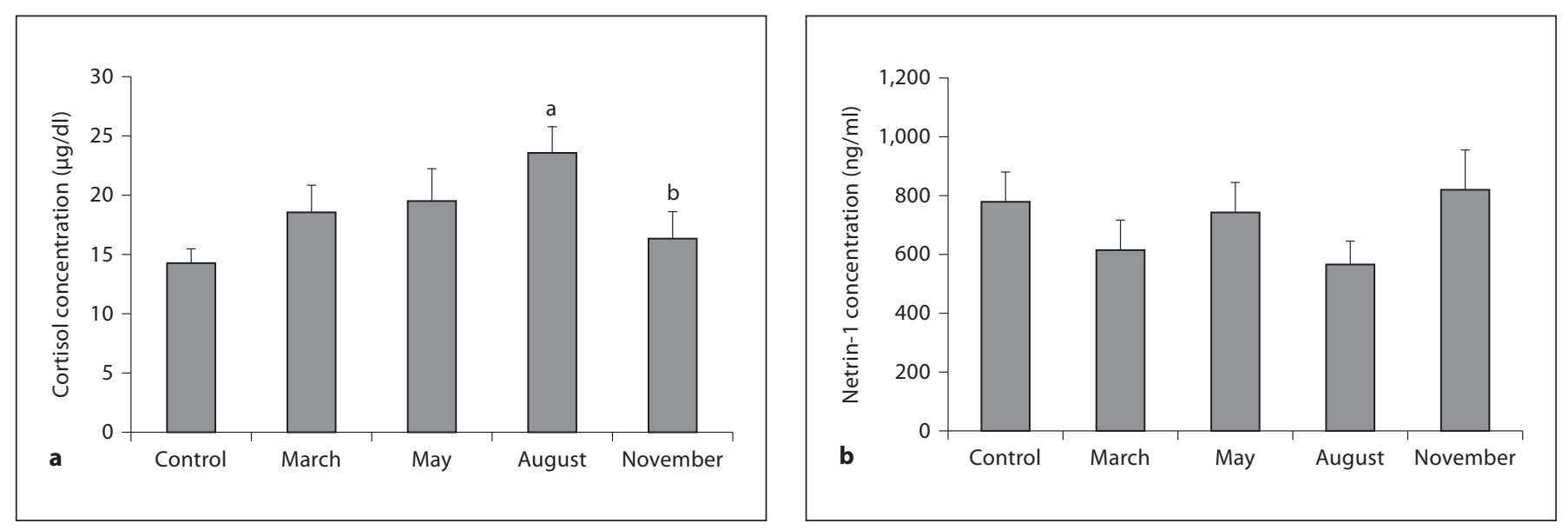

Fig. 4. Sequential variation in serum cortisol (a) and netrin-1 (b) levels in Indian Antarctic expeditioners before leaving India (control) and during their stay at Maitri, Antarctica, in March, May, August and November. Data are presented as means \pm SEs. $\mathbf{a}^{\mathrm{a}} \mathrm{p}<0.05$ August vs. control, ${ }^{\mathrm{b}} \mathrm{p}<0.05$ November vs. August.

The IFN- $\gamma$ level increased in March and May while, on the other hand, TGF- $\beta$ showed a significant decrease in March, May and August; the IgA level increased in Antarctic winter in samples compared with their baseline control levels.

There are few reports on the cytokine profile of Antarctic expeditioners during short- and long-term stays. The Australian National Antarctic Research Expedition (ANARE) has been conducting immunological studies on personnel staying in Antarctica over the winter (winterers) [15]. Work in the 1990s indicated that Antarctic winterers had lowered immunological responsiveness. One of the studies showed that harsh environmental conditions, combined with psychosocial, physical and other stresses associated with working and living in physical isolation during the Antarctic winter, resulted in altered immune function [16, 17, 25]. Tingate et al. [8] (1997) reported alterations in $\mathrm{T}$ cell function, including depression of cell-mediated immunity and a 50\% reduction in $\mathrm{T}$ cell proliferation to phytohemagglutinin mitogen in addition to altered cytokine production. Shearer et al. [2] (2002) reported increased proinflammatory cytokines in winter expeditioners, which is in agreement with our study. In contrast to our findings, an Italian study showed a marked decrease in serum cytokine levels in human subjects after prolonged exposure to a cold environment [9]. Shirai et al. [3] have reported that exposure to an Antarctic winter induced a dramatic decrease in the levels of TNF- $\alpha$, IL-1Ra, IL- 6 and IL- $1 \beta$ in serum samples. No specific patterns of disease have, as yet, been identified by these immunological studies; however, these findings are important because there might be long-term health implications. Research is this field is hindered by several factors, including small population sizes, short lifetime exposure to the Antarctic environment and the presence of multiple variables. Various types of stress have a certain effect on the Th1/Th2 balance [18]. It is well known that an imbalance in Th1/Th2 immunity is associated with an increased risk for various immune-related diseases [19]. However, it has not been established whether cold exposure induces either a Th1- or a Th2-biased immune status. Therefore, we were eager to study the effect of Antarctic exposure on Th1/Th2 balance, and an analysis of serum IL- 4 and IFN- $\gamma$ was done. We found that exposure to an Antarctic winter generated a bias toward Th1 immunity.

Most of the stress-related studies have shown increased levels of serum IgA [19-21, 24]. Our study also reports increased sIgA levels in wintering expeditioners compared with their baseline levels. The possible reason for increased serum IgA levels is not yet known; however, we speculate that generation of IgA is more dependent on $\mathrm{T}$ helper cells than IgG or IgM [22]. No definite factor is known so far that might acts as a stimulus for elevation of IgA in Antarctic expeditioners; however, these findings do not rule out a possible role of the hypothalamuspituitary-adrenal axis response to stress in modulating immunoglobulin production [23].

We have further investigated the levels of cortisol and netrin-1 to show the neuro-endocrine immune interac- 
tion in the serum samples of winter expeditioners and found that netrin-1 levels were not significantly altered. While cortisol levels were significantly increased during the winter stay in Antarctica. These data support that exposure to Antarctic winter leads to proinflammatory cytokine generation.

Hence, our study suggests that overwintering in Antarctica affects neuroendocrine immune interaction in favor of Th1 cytokines. Serum sIgA levels could be a potential biomarker of stress in extreme environmental conditions.

\section{Acknowledgement}

The authors are thankful to all the 28th Indian Antarctic expeditioners who have voluntarily given their blood sample for conducting this study. Special thanks to the National Centre for Antarctic and Ocean Research, India for providing all the facilities required for the study. K.P.M. was summer member and A.P.Y. was winter member of the 28th Indian Antarctic Expedition. The study was supported by DRDO, Ministry of Defence, Government of India.

\section{References}

1 Shephard RJ, Shek PN: Cold exposure and immune function. Can J Physiol Pharmacol 1998;76:828-836.

-2 Shearer WT, Lee BN, Cron SG, Rosenblatt HM, Smith EO, Lugg DJ: Suppression of human anti-inflammatory plasma cytokines IL-10 and IL-1RA with elevation of proinflammatory cytokine IFN- $\gamma$ during the isolation of the Antarctic winter. J Allergy Clin Immunol 2002;109:854-857.

-3 Shirai T, Magara KK, Motohashi S, Yamashita M, Kimura M, Suwazomo Y, Nogawa K, Kuriyama T, Masaru Taniguchi M, Nakayama T: TH1-biased immunity induced by exposure to Antarctic winter. J Allergy Clin Immunol 2003;111:1353-1356.

4 Roy DD, Deb NC: Role of stress profiles of scientists and defense personnel in 15th Antarctic Expedition. 15th IEA Scientific Report, 1999, vol13, pp 371-375.

5 Lugg D, Shepanek M: Space analogue studies in Antarctica. Acta Astronaut 1999;44:693699.

-6 Muller HK, Lugg DJ, Quinn D: Cell mediated immunity in Antarctic wintering personnel: 1984-1992. Immunol Cell Biol 1995;73: 316-320.

7 Williams DL, Climie A, Muller HK, Lugg DJ: Cell-mediated immunity in healthy adults in Antarctica and the subantarctic. J Clin Lab Immunol 1986;20:43-49.

-8 Tingate TR, Lugg DJ, Muller HK, Stowe RP, Pierson DL: Antarctic isolation: immune and viral studies. Immunol Cell Biol 1997;75: 275-283.
-9 Tringali G, Farrace S, Ragazzoni E, Dello Russo C, Piscitelli R, Preziosi P: Circulating interleukin-1-beta levels after acute and prolonged exposure to low temperatures: human and rat studies. Neuroimmunomodulation 2000;7:177-181.

10 Aarstad HJ, Gaudernack G, Seljelid R: Stress causes reduced natural killer activity in mice. Scand J Immunol 1983;18:461-464.

-11 Shu J, Stevenson JR, Zhou X: Modulation of cellular immune responses by cold water swim stress in the rat. Dev Comp Immunol 1993; 17:357-371.

12 Cheng GJ, Morrow-Tesch JL, Beller DI, Levy EM, Black PH: Immunosuppression in mice induced by cold water stress. Brain Behav Immun 1990;4:278-291.

13 Dantzer R, Mormede P: Psychoneuroimmunology of stress; In Leonard, BE, Miller K (eds): Stress, the Immune System and Psychiatry. Chichester, Wiley, pp 48-83.

14 Maes M, Hendriks D, Gastel AV, Demedts P, Wauters A, Neels H, Janca, Scharpé S: Effects of psychological stress on serum immunoglobulin, complement and acute phase protein concentrations in normal volunteers. Psychoneuroendocrinology 1997;22:397409.

15 Olson JJ: Antarctica: a review of recent medical research. Trends in Pharmacol Sci 2002; 23:487-491.

16 Williams DL, Climie A, Muller HK, Lugg DJ: Cell-mediated immunity in healthy adults in Antarctica and the sub-Antarctic. J Clin Lab Immunol 1986;20:43-49.

17 Muller HK, Lugg DJ, Quinn D: Cell mediated immunity in Antarctic wintering personnel 1984-92. Immunol Cell Biol 1995;73: 316-320.
18 Elenkov IJ, Chrousos GP: Stress hormones, Th1/Th2 patterns, pro/anti-inflammatory cytokines and susceptibility to disease. Trends Endocrinol Metab 1999;10:359-368.

19 Spellberg B, Edwards JE Jr: Type 1/type $2 \mathrm{im}$ munity in infectious diseases. Clin Infect Dis 2001;32:76-102.

20 Mishra KP, Chauhan UK, Naik S: Effect of lead exposure on serum immunoglobulins and reactive nitrogen and oxygen intermediate. Hum Exp Toxicol 2006;25:661-665.

21 Williamson DM, White MC, Poole C, Kleinbaum D, Vogt R, North K: Evaluation of serum immunoglobulins among individuals living near six Superfund sites. Environ Health Perspect 2006;114:1065-1071.

22 Teitsson I, Withrington RH, Seifert MH, Valdimarsson H: Prospective study of early rheumatoid arthritis. I. Prognostic value of IgA rheumatoid factor. Ann Rheum Dis 1984;43:673.

23 Fukata J, Imura H, Nakao K: Cytokines as mediators in the regulation of the hypothalamic-pituitary-adrenocortical function. J Endocrinol Invest 1993;16:141-155.

24 Mishra KP, Yadav AP, Shweta, Chanda S, Majumdar D, Ganju L: Serum levels of immunoglobulins (IgG, IgA, IgM) in Antarctic summer expeditioners and their relationship with seasickness. Cell Immunol 2011;271: 29-35.

25 Mishra KP, Yadav AP, Shweta, Chanda S, Ganju L, Majumdar D, Ilavazhagan G. Shipborne journey induces Th1 cytokines level in Antarctic summer expeditioners. Immunol Invest 2010;39:770-779. 